\title{
White Oppression and Black Resistance in Toni Morrison's The Bluest Eye
}

\author{
MHD Noor Al-Abbood \\ Correspondence: MHD Noor Al-Abbood, Department of Foreign Languages, Taif University, Kingdom of Saudi Arabia.
}

Received: January 23, 2019 Accepted: February 15, 2019 Online Published: February 20, 2019

doi:10.11114/ijecs.v2i1.3987

URL: https://doi.org/10.11114/ijecs.v2i1.3987

\begin{abstract}
Many critical interpretations of Morrison's The Bluest Eye are driven by the belief that the novel pessimistically depicts an African American community so helplessly captivated by an insidious white aesthetic ideology that it is incapable of resistance, self-regeneration, or change. Pointing out the flawed premises of these readings, this article argues that the novel presents rather an effective example of resistance to the dominant white ideology thematically and formally. Morrison's deconstructive rewriting of the "Dick and Jane" primer effectively subverts the terms of the white oppressive discourse and demolishes its ideological foundations, thus paving the way for African American self-affirmation. This is reflected in Claudia's increasing awareness of, and mounting rebellion against, the destructive white aesthetic. Her rejection of the white beauty myth, demonstrated by her confused early childhood's destruction of white baby dolls, culminates in a more sophisticated perception of the operation of this myth and in a radical retrieval and re-affirmation of the black beauty and worth which the white beauty myth denies in order to legitimate itself and establish its hegemony. The article argues that the radical resistance to the dehumanizing white ideology Claudia develops is, like Morrison's formal deconstructive project, quite indebted to African American music and, more crucially, to the rich heritage behind it. The article concludes by emphasizing that in the world depicted in The Bluest Eye possibilities of resistance and chances of survival are vitally dependent on the strength of one's connection to African American culture and heritage, as the story of Claudia's survival proves.
\end{abstract}

Keywords: Toni Morrison, The Bluest Eye, hegemony, white aesthetic ideology, resistance

\section{Introduction: A Hopelessly Doomed World?}

Focusing on the extent of the black community's internalization of white values and ideals of beauty and Pecola's tragic fate, a number of critics have claimed that Morrison's The Bluest Eye represents formally and thematically a completely doomed black American world incapable of resistance, self-regeneration, or change. For example, Linda Dittmar (1990), Keith E. Byerman (1993), Patrice Cormier-Hamilton (1994), and Malin Walther Pereira (1997) all have complained that the novel displays the success of the white racist ideology in shaping and controlling black subjectivity, rather than the latter's successful resistance to it. Byerman (1993) contends that "In The Bluest Eye ... the destructiveness of control rather than the creativity of negation predominates" (p. 100). Cormier-Hamilton (1994) seems also to hold such a view. For her, Morrison's novel shows the successful operation of the dominant white ideology through the characters' unquestioning imitation of the prevailing modes of the dominant white tradition and their internalization of its aesthetic standards. Moreover, insofar as the characters remain under white control, failing to form a different identity able to resist the hegemony of the white aesthetic, The Bluest Eye depicts a general condition well known and widely studied in minority and colonial cultures. More specifically, such a dominant/dominated condition represents the first stage of a three-phased paradigm of development that all minorities and dominated communities undergo in their relationship to the hegemonic culture. In support of her argument, Cormier-Hamilton cites Elaine Showalter's three-stage model of female subcultures, which turns out to be no more than a re-statement of the three-phase schema Frantz Fanon (1967) envisages in his account of the decolonization of the native mind and its liberation from the power of colonial discourse (pp. 178-9). In "The Female Tradition," Showalter (1977) describes the first phase a subculture or minority experiences as an extended period of "imitation of the prevailing modes of the dominant tradition, and internalization of its standards of art and its views on social roles." However, when a minority culture values the unique characteristics of its identity and gains a better sense of its power, it progresses collectively into a second phase marked by a "protest against these standards and values, and ... a demand for autonomy." A further third phase is described as a period of "self-discovery, a turning inward freed from some of the dependency of opposition, a search for identity" (p. 13). In the light of such a "stage-ist" model, Cormier-Hamilton (1994) concludes that "In studying Pecola from a psychological perspective, one can say that Pecola and much of her community are trapped in Showalter's first phase of growth for a subculture" (p. 116). 
In her post-colonial study of the development of Morrison's work, Pereira (1997) seems to revalorize the same minority/Fanonian model that Cormier-Hamilton quotes in defence of her view, arguing that Morrison's early work focuses on the destructive effects of white American "colonization" on African American individuals and the community, while her later work shifts focus to explore "decolonized" African American culture and history (p. 72). Like Cormier-Hamilton, Pereira implies that The Bluest Eye, as Morrison's earliest work, represents an African American world "totally" colonized by white ideology that it lacks the power to imagine itself in terms other than those scripted by the white oppressor. She argues that up to Tar Baby, Morrison's major female characters are "engulfed by white ideals of beauty." Pecola's obsession with white beauty and her eventual madness at the end of the novel mirrors "a cultural insanity that threatens the black community's identity and strength" (p. 74). However, in later works such as Tar Baby (1981) and Beloved (1987), which supposedly depict a process of "decolonization" at work, the absolute dominance of the white aesthetic portrayed in The Bluest Eye gradually gives way to a "plurality of beauty ideals," thus granting black characters "aesthetic and cultural choices" (p. 75). Arguing from a different perspective, Justine Baillie (2003) seems also to share this view. She maintains that "Morrison was later to regret this representation of Pecola as a pitiful victim, and in her subsequent novels marginal existence no longer precludes choice and will” (p. 35).

However, Pereira's real argument is not only that The Bluest Eye represents a black world absolutely dominated by colonial forces, but also that the nature and scope of its author's project is somehow limited by the dependency of opposition. For example, the fact that "The Bluest Eye is framed with a deconstructive dialogue with the 'Dick and Jane' children's books" weakens Morrison's radical efforts because she remains dependent on the terms of colonial discourse, even when she is engaged in their subversion. Pereira asserts that only in later works Morrison's writing "breaks free" from the dominance of "white ideas, aesthetic or otherwise" - a liberation that is signalled by a change of focus in such texts as Beloved and $J a z z$ to broach issues in "black history" primarily from "an African American cultural perspective" (1997, p. 74).

From a related perspective, Robin Small-McCarthy (1995) maintains that "Morrison's progressive development of musical discursive strategies began with subtle allusions to sound in The Bluest Eye (1970), and gradually moved toward a comprehensive jazz aesthetic in Jazz (1992)" (p. 377). Appropriating this development into her schema, however, Pereira (1997) argues that the movement from the blues to a jazz aesthetic, as can be inferred from her choice of titles, not only chimes with, but also accounts to a large extent for, the increasingly positive thrust towards black self-identity and the quest for freedom in Morrison's evolving writing career. Structurally, there is rarely much deviation from the basic, predetermined structure of a blues song, while jazz is founded on improvisation and syncopated rhythms that allow each musician in the ensemble to add their own interpretation based on their mood and their interaction with the rest of the ensemble and even with the audience. Comparatively speaking, contends Pereira, Morrison's shift to jazz in later works opens vistas for her to revise her earlier blues-styled narratives and explore alternative implications and possibilities. For example, 'Unlike Pecola, Violet is not 'the bluest I,' although she has the blues; instead, she is violet, a color suggesting a more nuanced understanding of the complex realities before her" (p. 78). According to Pereira, Jazz problematizes signification showing that meaning, while multiple, "cannot finally be determined." The free play of signifiers separates cause and effect, arche and telos: "[T]here is a freedom and lightheartedness associated with signifying." This freedom resists forced closure of structures of signification as meanings remain at play never resting with a final signified (p. 77). This liberates the novel and its characters from the power of oppressive and deep-seated meanings and values - the transcendental signifieds valorized by "the ideology of the white aesthetic," to appropriate the title of Terry Eagleton's illuminating book (1990). ${ }^{1}$ In contrast, implies Pereira, The Bluest Eye leaves signs of white beauty unchallenged to determine the course of the lives of black characters and render Pecola invisible (p. 77; cf. Walther, 1990, p. 777). As Mermann-Jozwiak (2001) points out in a related context, "there is no Derridean free play at work in the interpretation of [Pecola's] blackness; unequivocally, in her case, this blackness is read as ugliness, and it is this reading that condemns Pecola" (p. 189).

Pereira in effect implies that Morrison's blues strategy in The Bluest Eye hampers rather than enables a better conception of resistance, an implication that is, as we shall see, untenable. She would have us believe that both Morrison and her characters had to wait until Jazz (1992) to be able to free themselves from "colonial discourse" and reap the "deconstructive" benefits of jazz, when jazz has been in fact always a strong and inspiring influence on Morrison's entire work and from her very beginning with The Bluest Eye, as Morrison herself has explained on several occasions:

Jazz always keeps you on the edge. There is no final chord. There is something underneath that is incomplete. There is always something else that you want from the music. I want my books to be like

\footnotetext{
${ }^{1}$ Significantly, part of Eagleton's argument is that the ideology of the Western aesthetic establishes the white bourgeois subject as a universal subject (see especially p. 19).
} 
that - because I want that feeling of something held in reserve and the sense that there is more - that you can't have it all right now. (1994, p. 155).

This comparable relationship with jazz is reiterated in a more recent interview when she explains why "I Want to Write Like a Good Jazz Musician” (Morrison, 2008a).

Ironically, Pereira's study ignores Dittmar's earlier, similarly “deconstructive" reading of The Bluest Eye which completely spurns the unmistakable allusion to the blues in the novel's title and proceeds to interpret the work through an exclusively jazz lens. The irony becomes all the greater when we realize that Dittmar's basic argument is that, regardless of the stated political stand of the author, the jazz-modelled structure of the novel resists closure, and this resistance "encourages an ambivalent mode of reading" and, therefore, undermines any coherent and politically effective response to the racist oppression the novel so clearly depicts: "The thematic urgency the text establishes about finding ways to escape the tyranny of racist values gets undermined by uncertainty" (1990, pp. 139; 148). What Pereira regards as an increasing improvement in Morrison's narrative and discursive techniques - the dissemination and therefore the indeterminacy of meaning, the freedom and lightheartedness associated with signifying - is seen by Dittmar as Morrison's indirection and hesitation, which effectively let the white racist system off the hook (pp.151, 142). In sum, Dittmar's deconstructive reading ironically faults the very jazz-modelled narrative strategies believed by Pereira to enhance resistance and the quest for freedom for precisely thwarting resistance in the text and blunting the edge of Morrison's political and social criticism.

Now all these critical interpretations seem problematic and overstated in suggesting that The Bluest Eye presents a hopelessly doomed world without the consciousness or resources to resist white hegemonic discourse, or that it fails to launch an effective and decisive form of resistance on account of its jazz or blues narrative strategies. In fact, the claim that The Bluest Eye removes or downplays resistance could easily be reversed by showing that it is the methods of analysis employed by these critics which gives short shrift to, or totally eliminates, resistance from The Bluest Eye in particular and Morrison's early work in general. For instance, the model of development Pereira and Cormier-Hamilton apply to Morrison's work is deeply flawed because it reinstates a modified version of the dominant "grand narratives" which post-colonial theory has debunked. In addition, it implies a shift from "total acceptance" or internalization to "total disregard" of white racist ideology, which is surely an oversimplification of the complex relationship between the dominant ideology and the "colonized" black subject, precisely because it writes off evidence of creative and varied forms of resistance. Even if one accepts such schemas, one has to acknowledge that they are in fact more fluid than clearly-demarcated or clearly-cut (Al-Abbood, 2012). As Cormier-Hamilton (1994) herself realizes when considering Claudia's rebellion against the white ideals of beauty in her community, within the first so-called phase of imitation and internalization of dominant oppressive ideology, there also exist resistance and the quest for freedom and self-identity (p. 121).

It is this resistance, which the above mentioned interpretations downplay or fail to acknowledge, that will be the focus of this article. For The Bluest Eye does not merely narrate the tragic downfall of Pecola and her family; it also documents the gradual coming to consciousness of Claudia, her effective resistance and ultimate survival. Madonne M. Miner (1985) argues that though Pecola's life is tragic, destroyed as it is by a coalition of the forces of racist white culture and their black intraracist counterparts, The Bluest Eye itself is not a tragedy because it also shows the resistance and survival of the MacTeer sisters Claudia and Frieda: "I cannot read The Bluest Eye as tragedy...although the novel documents the sacrifice of one black woman, it attests to the survival of two others-a survival ... filled with hardship, but also with hope" (p. 189). Similarly, Naomi Rokotnitz (2007) maintains that Morrison's novel traces the process not only of Pecola's "(self-) destruction" but also of Claudia's "self-construction," showing "the dramatic differences in character and circumstances that enable one to become a defiantly independent individual, while the other is abused, marginalized and finally driven to insanity" (p. 386).

Building on the suggestions of Miner and Rokotniz, and without leaving the post-colonial and deconstructive frameworks within which Cormier-Hamilton, Pereira, and Dittmar mount their critiques of The Bluest Eye, it will be my contention in this article that the novel presents an effective example of resistance to the dominant white ideology thematically and formally. Rather than limiting her project by a dependency of opposition, Morrison's deconstructive rewriting of the "Dick and Jane" primer effectively subverts the terms of the white oppressive discourse and demolishes their ideological foundations, simultaneously paving the way for an alternative African American discourse. This dismantling process takes place in tandem with Claudia's increasing awareness of, and mounting rebellion against, the white aesthetic. Rather than being or remaining "engulfed by ideals of white beauty," Claudia progressively develops more productive forms of anti-racist resistance, beginning with an innocent destruction of white dolls but culminating in the politically effective and successful affirmation that "black is beautiful." Whether The Bluest Eye is modelled on jazz or the blues, African American music, and more crucially the rich heritage behind it, proves effective and decisive in such formal and thematic resistance. Music lends Morrison's effective formal strategies to topple the dominant racist discourse as much as it fosters in Claudia a positive black identity capable of resisting and surviving the damaging 
influence of the ideology of the white aesthetic. If one juxtaposes the lives of the Breedloves and the MacTeers, it can be easily seen that Morrison's novel shows that possibilities of resistance and chances of survival are vitally dependent on the strength of one's connection to African American culture and heritage, as the story of Claudia's survival proves.

\section{Deconstruction of the Myths of "Dick and Jane"}

Shelley Wong (1990) contends that form and technique in The Bluest Eye are of particular importance, not least because "while the story itself may fall within the thematic bounds of bleakness, the way in which it is told can constitute a means of resistance to both personal despair and cultural oppression" (pp. 472-3). One way to observe the operation of such narrative strategies and gauge the efficacy of their unsettling effect is to scrutinize Morrison's engagement with the Dick and Jane school primer, which is part of a series of books widely used in the 1930's and 1940's to teach American children to read (Werrlein, 2005). The passage Morrison quotes begins as follows:

Here is the house. It is green and white. It has a red door. It is very pretty. Here is the family. Mother, Father, Dick and Jane live in the green-and-white house. They are very happy. (2004, p. 8)

This seemingly innocent text is in fact representative of both ideologically insidious and racially exclusivist white discourse. As Tessa Roynon (2013) observes, it "stands as the ur-text of the ideology that has come to be called "whiteness," since it inculcates in American children the superiority of white middle-class values and ideals through myths about the perfect home and family (pp. 17-8). As such, it recalls Morrison's later argument in Playing in the Dark that dominant forms of language "can powerfully evoke and enforce hidden signs of racial superiority, cultural hegemony, and dismissive 'othering' of people and language" (1993, p. x). In The Nobel Lecture in Literature of 1993, she reiterates this view and adds that dominant language, as a conduit of oppressive ideology, does more than represent violence against minorities - it is itself a form of violence deployed in extending white hegemony and oppression: "Oppressive language does more than represent violence; it is violence; does more than represent the limits of knowledge; it limits knowledge. .. [I]t must be rejected, altered, and exposed" (2008b, p. 201). From this perspective, The Bluest Eye can be regarded as Morrison's effort to reject, alter and expose the ideologically racist representations implicit in the seemingly innocuous Dick and Jane primer and to subvert the oppressive value system that underpins them. This is implemented by removing the punctuation and capitalization and running words together in the primer's text. The above quoted passage re-appears in Morrison's text broken up as such:

Hereisthehouseitisgreenandwhiteithasareddooritisveryprettyhereisthefamilymtherfatherdickandjaneliv einthegreenandwhitehousetheyareveryhappyseejaneshehasareddressshewants ... . (2004, pp.8-9)

The unsettling effect of this seemingly simple gesture is deep and extensive because it exposes the ideologically static and settled meanings in dominant American cultural texts, such as the Dick and Jane primer. As Wong (1990) argues, by employing such a subversive technique, the novel "force[s] one to reevaluate the cultural sign-posts which give the measure to one's life." In fact, running words together and breaking lines without respect for the integrity of the word, "Morrison collapses those measures altogether, forcing one to pick one's way through a welter of potential signification" (p. 473). Pace Pereira, this procedure puts The Bluest Eye on a par with Jazz in that it problematizes signification and subverts, through the omission of punctuation and capitalization, the privileged transcendental signifieds of the dominant white culture.

On this very ground, The Bluest Eye can be said to resist closure in a sense quite different from what Dittmar means. The closure in question is produced by ideologically settled meanings and values in dominant American cultural texts, such as the Dick and Jane primer, which valorize white supremacy by excluding and oppressing minorities. The novel's subversion of the Dick and Jane primer unsettles these established meanings, and this constitutes an effective resistance to this white-imposed closure. As Wong (1990) contends, "The Bluest Eye opens with a tuition in closure. In a passage rendered in the style of the 'Dick and Jane' series of primers, the novel lays bare the syntax of static isolation at the center of our cultural texts" (p. 471). Again pace Dittmar, Claudia's choosing to tell "how" rather than "why" Pecola's tragedy has occurred is not an evasive gesture, but a further tuition in closure - a closure that shuts America's Pecolas from the dominant white narratives and divests them of the right and the chance to achieve individuality and full humanity (cf. Dittmar, 1990, p. 142). As Wong (1990) observes, Morrison "is interested in, not questions of final causes, but questions of process, questions about how process comes to be shut down" (p. 471). In fact, the novel shows that not only Pecola's healthy process of development of identity and individuality "comes to be shut down," but also that of her parents, her brother, a host of other characters in the black world depicted in the novel, and countless African Americans in the real world outside. As Morrison points out in her 1993 Afterword to The Bluest Eye, "some aspects of [Pecola's] woundability were lodged in all young girls" (2004, p. 188). From this perspective, one cannot fault Morrison, as Dittmar (1990) does, for beautifying some of her morally condemnable characters, as Geraldine and the brown girls from Mobile and Cholly (see for example, Dittmar, 1990, pp. 148-50). Morrison's implied message is that all these characters could have been better people if given the chance. This implication is itself an indictment of a racist culture that excludes, corrupts, and destroys these potentially good people. When Claudia realizes that "it's too late" to 
intervene on Pecola's behalf and set things right because "The damage done was total," she ruefully mourns Pecola's "assassinated" beauty - all that which could have been but never was allowed to be (Morrison, 2004, pp. 186, 184, 186).

Undoubtedly, Pecola's misfortune is grievous, and Claudia's sad realization suggests the extent of both the dominant culture's dehumanization of the black community and the latter's abdication of its responsibilities. Nevertheless, the fact that Claudia is able to survive under the same circumstances and develop both the consciousness to understand the forces that have destroyed Pecola and the authority to tell her story salvages the novel from falling into pessimism and suggests hope (Salvatore, 2002, p. 159). It is this hope that the novel translates into vigorous and beautiful language, even when things seem hopeless and distressing. In this sense, there is no contradiction or ambivalence in Morrison's use of beautiful language to describe her characters and their realities, as Dittmar would have us believe (1990, p. 150). Anne T. Salvatore (2002), who views The Bluest Eye as a bildungsroman, argues that despite Pecola's failure, Claudia's success, "even if it is not necessarily coupled with a traditional resolution of overwhelming problems, suggests that Morrison's powerfully eloquent language is not contradictory to her meaning, ... but instead stands as linguistic evidence of a world that Morrison believes to be ultimately redeemable, even potentially beautiful" (p. 175).

\section{Claudia's "Conversion": From Rejection of the White Aesthetic to More Rejection of It}

However, in many critical interpretations of the text, Claudia's survival, much less her success, is often not acknowledged. On the contrary, it is believed that in the course of her maturing, Claudia gradually renounces her youthful opposition to the white aesthetic and embraces, like everyone one else in her community, the dominant values and ideals of white culture. In doing so, she reinforces her own subjugation and goes on, again like everyone else in the community, playing right into the hand of the white oppressor. Such interpretations are based on some of Claudia's own statements describing her relationship to the white beauty myth. Claudia says that she, as a child, could not identify with Shirley Temple, because "Younger than both Frieda and Pecola, I had not yet arrived at the turning point in the development of my psyche which would allow me to love her." A few passages later, however, she tells us that has undergone a "conversion from pristine sadism to fabricated hatred to fraudulent love.... I learned much later to worship her [Shirley Temple], just as I learned to delight in cleanliness, knowing, even as I learned, that the change was adjustment without improvement" (Morrison, 2004, pp. 21, 23-4). Taken at face value, Claudia's revelations would suggest that her "conversion" is a change from total disregard for the white aesthetic to its opposite, that is, unquestioning acceptance of the white beauty myth and total identification with its icons. Indeed, most critics and commentators, even those who otherwise credit Claudia for a measure of resistance, believe that Claudia is describing here her gradual capitulation to the ideology of the white aesthetic. Jane Kuenz (1993) argues that Claudia's self-perception is shaped by "commodities like the Shirley Temple cups that proscribe appearance and behavior in accordance with the images they project." The older Claudia not only comes to embrace white values and ideals but also to identify herself with Shirley Temple (p. 423). On his part, Byerman (1993) acknowledges that in the course of her development Claudia gains the knowledge that enables her to see better into the workings of white racist ideology and its effects on the black community, but he nevertheless maintains that she fails in the end "because she refuses to live in her demystified knowledge." For translating this knowledge into concrete action requires perpetual opposition and negation, which Claudia cannot sustain, especially when there is no hope of winning the struggle. Although she serves as "a rebel for a while," he writes, "Claudia ultimately fails" (p. 105). Commenting on her "reformation," Cat Moses (1999) argues likewise that "Claudia tells us that she comes to embrace [the white] aesthetic tentatively, reluctantly, and consciously," although Moses goes on to suggest that such reformation describes only her changed attitude later in her childhood, not her maturity (p. 627; see also Rokotnitz, 2007, p. 400, for a similar view). Baillie (2003) also maintains that "Even Claudia ... succumbs to the power of the beauty myth." Echoing Byerman, however, Baillie ascribes Claudia's surrender to the white aesthetic not to a genuine conviction on Claudia's part but to her realization that it is "pointless to contest its commanding power with dumb, unmediated aggression" (p. 27).

However, Claudia's "conversion" statement is neither definitive of her attitude towards the white aesthetic, nor by any means her "last word" on the subject, so to speak, and therefore should not be read as though it were. Moreover, in all these readings, Claudia's crucial qualification that her "conversion" is "adjustment without improvement" is largely disregarded. Therefore, to grasp the full meaning of Claudia, one has to consider her statement not only within the context in which it occurs, but also with regard to the development of her consciousness in the course of the novel, especially as it is revealed in her other comments or responses to the major events in the narrative. When Claudia says she could not love Shirley Temple she means that the ideology of the white aesthetic has not yet taken root in her at that age. In her youth and innocence, she and her sister Frieda have lived at ease with their bodies and the fact of their blackness: "we were still in love with ourselves then. We felt comfortable in our skins ... admired our dirt, cultivated our scars, and could not comprehend this unworthiness" for not having the "Thing" that white baby dolls, Shirley Temple and Maureen Peal have (Morrison, 2004, p. 70). As Claudia narrates, her inability to relate to the white aesthetic and identify with the white goddesses of the silver screen goes back in fact to a still earlier stage of her childhood and is 
evidenced by her destruction of the white baby doll given to her by her relatives as a Christmas gift. At that age, Claudia also says that she could not understand why such a plastic doll is universally regarded as ideal beauty. That is why she dismembers it in order to find "what it was that all the world said was loveable," "to see of what it was made, to discover the dearness, to find the beauty" (p. 22). Destruction of white dolls then turns into violence against the little white girls in the neighbourhood (p. 23).

Thinking retrospectively about her childhood experiences, the mature Claudia disavows her destruction of white dolls and violence to white girls in the neighbourhood as "pristine sadism." She now realizes that her earlier destruction of the white doll and the violence to the white neighbourhood girls are socially inappropriate, perhaps a form of "misdirected anger and violence" as Baillie maintains (2003, p. 27). The novel shows in fact many instances of how anger and hatred, engendered by racial experiences, "often miss their mark," as Jerome Bump puts it (2010, p. 152). Anger and hatred can easily be converted into shame, self-loathing, self-laceration, and/or abuse of others. For example, the novel suggests that Cholly's rape of Pecola is the result of displacing onto his daughter the repressed shame, anger, and hatred which he experienced in his youth when he was "raped" by the white hunters (see Morrison, 2004, pp. 137, 147). Nevertheless, although the older Claudia distances herself from her childhood's anger and violence, her destruction of white dolls remains symbolically one of the most significant events in the novel. It shows how Claudia, even as a little child, realizes that the very idolization of such white dolls is a silent indictment of her for lacking something which plastic dolls have. This indictment would become later more obvious in "the honey voices of parents and aunts, the obedience in the eyes of our peers, the slippery light in the eyes of our teachers when they encountered the Maureen Peals of the world" (p. 70). Therefore, Susan Willis (1993) does not exaggerate when she argues that "When Claudia destroys these - dismembering the doll and poking its eyes out-her rebellion is not just aimed at the idea of beauty incarnated in a white model. She is also striking out against the horrifying dehumanization that acceptance of the model implies - both for the black who wears it as a mask and for the white who creates commodified images of the self" (p. 312). Neither does Alan Rice (1999) go too far when he contends that in destroying the white doll, "Claudia attempts a move toward autonomy from the white standards of beauty that oppress and constrict Pecola" (p. 144). For the destruction of white dolls indeed shows Claudia as a child who has a keen sense of justice, intent on fighting discrimination and false hierarchies of colour and the dehumanization they entail, but who has still neither the understanding nor the vocabulary to describe the ideology of the white aesthetic which everyone else around her has internalized (Baillie, 2003, p. 27; Bump, 2010, p. 152).

If the destruction of white dolls or violence against the neighbourhood white girls are the result of Claudia's early confused confrontations with the forces of racism and intraracism, a presumably older or more mature Claudia shows a much more advanced understanding of such forces when reflecting on the fight between Maureen on the one hand, and Frieda, Pecola and herself on the other. She realizes that there is "a thing" in white dolls and in Maureen which endows them with beauty and makes them loveable, although her understanding is still short of naming that "thing:" "And all the time we knew that Maureen Peal was not the Enemy and not worthy of such intense hatred. The Thing to fear was the Thing that made her beautiful, and not us" (Morrison, 2004, p. 70). As this statement indicates, Claudia here also realizes that her anger and hatred are "misdirected," or better, displaced from the real "Thing" or cause of anger onto Maureen Peal. However, the mature Claudia shows in her thoughts on the event of Cholly's burning down his family home and turning them outdoors that she now understands this "thing." It is an abstract ideological construct, a value produced by the white racist culture, which ultimately has the power to confer it on white dolls and the Maureen Peals of the world and withhold it from Claudia and the Pecolas of the world. More precisely, the white racist culture's definition of the self in opposition to a black inferior "other" has promoted a racial hierarchy of skin colour and a corresponding value system (Baillie, 2003, p. 27). As Claudia observes, the African Americans are doubly complicit in such a warped hierarchy of values that perpetuates their own subjugation (see also Rokotnitz, 2007, p. 388). Not only do they accept a white-defined identity and reinforce the inferior status that comes with it. They also reproduce the same oppressive racial hierarchy in the form of a black caste system that elevates lighter-skinned and financially better-off African Americans such as Geraldine, the Peals, and Soaphead Church, and excludes the poorest and darkest of the African Americans such as the MacTeers and the Breedloves:

Being a minority in both caste and class, we moved about anyway on the hem of life, struggling to consolidate our weaknesses and hang on, or to creep singly up into the major folds of the garment. Our peripheral existence, however, was something we had learned to live with—probably because it was abstract. (Morrison, 2004, p. 19)

It is the failure to understand such an "abstract" racist aesthetic and its ideological value system which makes Pecola deny her own beauty and accept the dominant culture's "negating and dehumanizing cultural definitions" of beauty and worth, and prompts young Claudia's "misdirected anger and violence" (Frye, 1986, p. 102; Baillie, 2003, pp. 26, 27; see also Rokotnitz, 2007, p. 388). 
This profound understanding of the white aesthetic and the black community's complicity in reinforcing it is further illuminated at the close of the narrative when Claudia finally explains the reason why Pecola has been destroyed. Pecola, she says, is literally "All of our waste which we dumped on her and which she absorbed. And all of our beauty, which was hers first and which she gave to us" (Morrison, 2004, p. 185). It is only through the denial of Pecola's beauty that members of the community, black and white, have complacently asserted their own smug sense of superiority. Here, Claudia's early destruction of white baby dolls in order to find the secret of their alleged beauty becomes symbolically all the more meaningful in the light of her and the novel's deeper, more extensive interrogation and final dismantling of white myths of beauty. As a child, Claudia has prayed that Pecola's yet unborn black baby may be given the chance to live "just to counteract the universal love of white baby dolls, Shirley Temples, and Maureen Peals" (p. 169). Now she knows that the beauty of white baby dolls, Shirley Temples, and Maureen Peals has been established only through constructing Pecola and other African American girls as ugly and inferior. In fact, it is here, more even than in the destruction of the white doll, that Claudia mimes Morrison's deconstruction of the "Dick and Jane" primer. Morrison has shown how texts such as the primer shore up the superiority of white middle-class values and ideals through insidiously denigrating and excluding African Americans. Similarly, Claudia here shows how white American beauty myths legitimate themselves and establish their hegemonic status by denying the beauty of Pecola and other African Americans. At the close of the narrative, the mature Claudia symbolically restores Pecola's denied beauty by affirming that there is "on the edge of [her] town, among the garbage and the sunflowers" all the "beauty of the world" (pp. 185, 186). Such is Claudia's radical version of the 1960's Black Power's reverberating slogan "black is beautiful."

In the light of this development, Claudia's "conversion" statement can be read as displaying a deep sense of self-knowledge and showing her gradually gaining self-affirmation and anti-racial subjectivity rather than acquiescing to the ideology of the white aesthetic. She cannot therefore be accused of swinging from a deep rejection of the white aesthetic to a deeper adoption of it. Claudia's is rather a conversion from misdirected anger and violence to more improved modes of understanding of the white aesthetic and more effective resistance to the destructive forces of racism and intraracism it unleashes. In fact, development in this sense is already suggested in her candid revelation that "the change" in her relationship to the white aesthetic is merely "adjustment without improvement." In other words, Claudia's conversion is a more practical strategy than her earlier "pristine sadism," driven by the pragmatic necessities of resistance and survival rather than the acceptance of the dominant white ideology. For, as Baillie (2003) puts it, Claudia has learned "how pointless it is to contest its commanding power with dumb, unmediated aggression." The mature Claudia develops other more effective means of resistance and rebellion against white oppression. Like Morrison herself, Claudia turns to language and story-telling to bear witness, record, and contest (p. 27). In sum, Claudia's conversion is a shift from a child's awkward and confused rejection of the ideology of the white aesthetic to a stronger, more effective, rejection of it.

As evidenced in her reflections and reminiscences, Claudia has developed the insights that enable her to look back into the events of her childhood and understand why things have taken such a tragic turn. This process of cognitive fathoming culminates in her analysis and understanding of the adverse conditions that led to Pecola's tragedy, including her own and the community's complicity in creating and exacerbating such hostile conditions. At the end of the narrative, she acknowledges "the ease with which [the] community scapegoats vulnerable individuals" (Roynon, 2013, p. 22), especially that "the town has an undiagnosed and unexamined history of producing women like Pecola," as the case of Auntie Julia suggests (Kuenz, 1993, p. 429; Morrison, 2004, p. 16). She admits that her earlier attempt to blame the "soil," "the earth," "the land," and "our town" for Pecola's destruction has been merely a form of guilty displacement and denial of the responsibility for Pecola's fate, and, as such, a continuation of the community's misguided efforts "focusing on the wrong front," as Jennifer Gillan puts it (2002, p. 285). "We are wrong," Claudia now admits, for "we had failed her" (Morrison, 2004, pp. 186, 185). This revelation shows that Claudia has attained the moral and political maturity that allows her to acknowledge both her own and the community's complicity in Pecola's fate, and, as such, to gain the ethical authority to tell Pecola's tragic story (Salvatore, 2002, p. 159).

Acknowledging Claudia's outstanding resistance to the white beauty myth, but at the same time implying its hegemonic power over the other characters, Inger-Anne Softing (1995) writes that "Claudia is the only character in this novel who consciously makes an attempt at deconstructing the ideology of the dominant society" (p. 90). Moses (1999) likewise points out that "the child Claudia seems to stand alone in her critique of a 'master' aesthetic that is internalized by nearly everyone in her community" (p. 627). Given the enormous racist and intraracist forces that have destroyed Pecola and lamed almost everyone else in the community, Claudia's admission is similarly a triumph, and it strengthens her status as a true heroine whose truthfulness, courage, and resilience are worthy of emulation. Furthermore, it demonstrates that "African American women can achieve true knowledge that, while sometimes horrifying, carries with it an ethical authority and definitive selfhood" (Salvatore, 2002, p. 157). This suggests that the black world depicted in The Bluest Eye, however gloomy, is certainly not hopeless. As the narrative of Claudia proves, there is hope for African Americans to 
succeed in resisting the forces of racism and intraracism and form a positive, independent African American identity.

\section{The Resonance of the African American Tradition}

If The Bluest Eye attests to the resistance and survival of Claudia, it also demonstrates that such resistance would not have been possible and successful without the empowering relationship the MacTeers maintain to their African American heritage. Morrison lays the utmost emphasis upon the African American tradition as a means of empowerment and resistance to white American hegemony. In The Bluest Eye, this tradition is suggested by and through traditional African American music. As we have seen above, whether The Bluest Eye emulates the blues or jazz, its affinity to traditional African American music is empowering. Music, it $t$ is recalled, lends Morrison the formal narrative and discursive tools to unsettle the deep-seated structures of white racist discourse and paves the way for African American self-affirmation. No less important, traditional African American music thematically also fosters a strong black identity and subjectivity grounded firmly in the African American tradition. In fact, it is this positive identity which enables Claudia's self-affirmation and resistance to the destructive white aesthetic.

The title of the novel - The Bluest Eye - strongly evokes the blues, and Pecola's story of suffering and downfall as a consequence of her misplaced desires for the bluest eyes gains even more suggestiveness by resonance with the plaintive themes of the blues tradition. However, as noted earlier, the blues at its core expresses not only suffering but also resilience and survival, and, perhaps more significantly, the traditional African American wisdom and values that enable resilience and ensure survival. The playwright August Wilson (1988) says that the blues provides "a way of processing information about Black life, particularly information about the nobility ... the beauty ... and the resiliency of Black life." Thus, if the resonance of the title is suggestive of Pecola's downfall as a consequence of her wistful yearning for the bluest eyes, it equally evokes Claudia's resilience which enables her to resist and survive the seduction of the blue eyes and the dominant white aesthetic as much as to appreciate nobility and beauty in her black community, as we have seen above. Moses (1999) captures this blues suggestiveness in her compelling argument that The Bluest Eye is modelled rhetorically and thematically on a traditional blues song, namely, the "St. Louis Blues," one of the earliest recorded and most popular blues songs of W. C. Handy. As Moses demonstrates, the "St. Louis Blues" song Claudia hears her mother singing on Saturdays "convey[s] a wealth of folk knowledge and cultural values" "crucial to a young black woman's survival in the 1930s and "40s" (pp. 624, 623). Significantly for the concerns of The Bluest Eye, the song inspires one to seek wisdom and better knowledge in the black community itself and in its authentic values and traditions, rather than in a white-centred culture that by definition excludes and oppresses the African Americans. It infuses one with a sense of hope, freedom and individual agency. For it shows that one can act and change one's fate instead of resigning oneself to suffering; that it is best to adapt to the unfavorable circumstances rather than simply give up and die. This is exactly what Claudia resourcefully and creatively does to survive the fate of being "engulfed" by racist and intraracist forces, and her "conversion" really denotes no more than an adaptive strategy, an adjustment in attitude and behaviour to better fight and survive rather than miserably succumb and fall.

Perhaps most important of all, the "St. Louis Blues" affirms African American beauty and the values of the funk. For example, the song militates against the white aesthetic, represented by such reified consumer beauty products as "diamon' rings ... / powder an'.. . store-bought hair," which captivate African Americans with images of superior white beauty and ultimately serve the interests of American capitalism. Moreover, the "St. Louis Blues" disavows both the white aesthetic and its intraracist equivalent - the caste prejudice based on shades of black skin colour which effectively isolates Pecola and other black members of the community, damages their self-image, and in certain cases drives some of them into insanity, as The Bluest Eye shows (Moses, 1999, p. 627; Pereira, 1997, p. 74). The woman speaker in "St. Louis Blues" describes her lover as "stovepipe brown." He is, she enthuses, "Blacker than midnight, teeth lak flags of truce / Blackest man in de whole St. Louis." It is his blackness that makes him even more aesthetically and sexually desirable, for "Blacker de berry, sweeter am de juice" (Moses, 1999, p. 626). Such affirmation and celebration of black beauty instill in Claudia a positive black identity that resists the destructive white aesthetic represented by white baby dolls and Shirley Temple and her black intraracist equivalent Maureen Peal with her "high yellow dream" complexion and her "two lynch ropes" of long brown hair (Morrison, 2004, p. 58). As we have seen above, it is this positive identity which also allows Claudia to appreciate African American culture and cultivate affection for her own black community. This is seen most clearly in her enthusiasm about the beauty of Pecola's yet unborn black baby and later at the end of the narrative in bearing witness to "all the beauty ... of the world" which is Pecola's (pp. 169, 185).

That Claudia receives the sustaining benefits of the blues and the African American tradition through her mother is crucial but unsurprising. In all Morrison's novels, black mothers play a paramount role in immunizing their children against racial prejudice and in instilling in them a positive sense of self, not only by conveying traditional African American values, but also by modelling them (see, Morrison, 1994, p. 140; Rigney, 1991, p. 10; Harris, 1991, p. 40). In The Bluest Eye Morrison accentuates this maternal culture-bearing role by pointing out the suffering that occurs in its absence (O'Reilly, 2004, pp. 124-5). Moses maintains that "Claudia's defiance is a learned and nurtured defiance, 
encouraged by a severe but loving mother who sings to her on Saturdays" (p. 627). By the same token, Pecola's self-hatred is a nurtured and learned pattern of behaviour encouraged by her self-depreciating mother and a community steeped in divisions and caste prejudice. Thus, Claudia's survival and Pecola's downfall are ascribed to the great difference in the role their mothers model for them, and beyond that, to the culture and values from which these role models are derived. Mrs MacTeer has preserved and passed on to her daughters African American values and traditions, while Pauline has been separated from her heritage and has embraced instead the values of the dominant culture (cf. Putnam, 2011). "My work," says Morrison, "bears witness and suggests who the outlaws were, who survived under what circumstances and why" (1994, p. 121). In the light of this revelation, The Bluet Eye implies that the MacTeers have survived the destructive influence of racist white ideals and values because they have retained a connection to a wealth of African American folk knowledge and cultural values, a connection basically lost to the Breedloves. In a related context, Christopher Douglas (2006) argues that, as part of her politics of "decolonization," "Morrison's writing has worked toward substantiating an African American cultural presence, though that presence is often, according to many critics, rendered through tropes of loss, nostalgia, dispossession, and grieving" (p. 161). As we have seen above, the novel indeed suggests such a positive African American presence by juxtaposing the successful adaptation of the MacTeers and the damaged lives of the Breedloves. Through such a contrast, the novel emphasizes the vitality of the African American cultural traditions for survival by showing the destructive effects of losing one's cultural identity and assimilating into the dominant white culture.

In conclusion, Claudia's survival and success are in many ways connected to her family's roots in the African American traditions. The values and aesthetics of this heritage enable Claudia to mature and develop the right modes of anti-racial consciousness and resistance that effectively translate Morrison's gesture of deconstructing the dominant ideology into African American self-affirmation: black is beautiful. Pecola is irredeemably damaged due to the black community's own complicity in reinforcing the power structures of the dominant white culture by remaining enthralled by its dehumanizing values and ideals. Nevertheless, Claudia's survival and success also demonstrate that the black community is ultimately redeemable. In so far as African Americans maintain connection to their own empowering traditions and values, they can develop the consciousness to understand the ideological nature of the white aesthetic and cultivate a proud sense of self capable of withstanding the insidious and pervasive power of its racist values and ideals.

\section{References}

Al-Abbood, M. N. (2012). Native Culture and Literature under Colonialism: Fanon's Theory of Native Resistance and Development. English Language and Literature Studies, 2(3), 121-133. https://doi.org/10.5539/ells.v2n3p121

Baillie, J. (2003). Contesting Ideologies: Deconstructing Racism in African-American Fiction. Women: A Cultural Review, 14(1), 20-37. https://doi.org/10.1080/0957404032000081683

Bump, J. (2010). Racism and Appearance in The Bluest Eye: A Template for an Ethical Emotive Criticism. College Literature. 37(2), 147-170. https://doi.org/10.1353/lit.0.0108

Byerman, K. E. (1993). Beyond Realism: The Fictions of Toni Morrison. In Gates and Appiah, (eds), 100-125.

Cormier-Hamilton, P. (1994). Black Naturalism and Toni Morrison: The Journey Away from Self-Love in The Bluest Eye. MELUS, 19(4), 109-127. https://doi.org/10.2307/468206

Dittmar, L. (1990). Will the Circle Be Unbroken? The Politics of Form in The Bluest Eye. Novel: A Forum on Fiction, 23(2), 137-155. https://doi.org/10.2307/1345735

Douglas, C. (2006). What The Bluest Eye Knows about Them: Culture, Race, Identity. American Literature, 78(1), 141-168. https://doi.org/10.1215/00029831-78-1-141

Eagleton, T. (1990). The Ideology of the Aesthetic. Oxford: Blackwell

Fanon, F. (1967). The Wretched of the Earth, (C. Farrington, Trans.). London: Penguin Books.

Frye, J. S. (1986). Living Stories, Telling Lives: Women and the Novel in Contemporary Experience. Ann Arbor: University of Michigan Press.

Gates, H. L., Jr., \& Appia, K. A. (Eds). (1993). Toni Morrison: Critical Perspectives Past and Present. New York: Amistad Press.

Gillan, J. (2002). Focusing on the Wrong Front: Historical Displacement, The Maginot Line, and The Bluest Eye. African American Review, 36(2), 283-298. https://doi.org/10.2307/1512261

Harris, T. (1991). Fiction and Folklore: The Novels of Toni Morrison. Knoxville: University of Tennessee Press.

Kuenz, J. (1993). The Bluest Eye: Notes on History, Community, and Black Female Subjectivity. African American Review 27(3), 421-31. https://doi.org/10.2307/3041932 
Mermann-Jozwiak, E. (2001). Re-membering the Body: Body politics in Toni Morrison's The Bluest Eye. Lit: Literature Interpretation Theory, 12(2), 189-203. https://doi.org/10.1080/10436920108580287

Miner, M. M. (1985). Lady No Longer Sings the Blues: Rape, Madness, and Silence in The Bluest Eye. In M. Pryse and H. J. Spillers (eds.), Conjuring: Black Women, Fiction, and Literary Tradition, 176-91. Bloomington: Indiana University Press.

Morrison, T. (1993). Playing in the Dark: Whiteness and the Literary Imagination. New York: Vintage.

Morrison, T. (1994). Conversations with Toni Morrison (D. Taylor-Guthrie, Ed.). Jackson: University Press of Mississippi.

Morrison, T. (2004, 1970). The Bluest Eye. New York: Rosetta Books.

Morrison, T. (2008a). Toni Morrison: Conversations. (C. C. Denard, Ed.) Jackson: University Press of Mississippi.

Morrison, T. (2008b). What Moves at the Margin: Selected Nonfiction. (C. C. Denard, Ed.) Jackson: University Press of Mississippi.

Moses, C. (1999). The Blues Aesthetic in Toni Morrison's The Bluest Eye. African American Review, 33(4), 623-637. http://www.jstor.org/stable/2901343.

O'Reilly, A. (2004). Toni Morrison and Motherhood: A Politics of the Heart. Albany: State University of New York Press.

Pereira, M. W. (1997). Periodizing Toni Morrison's Work from The Bluest Eye to Jazz: The Importance of Tar Baby. MELUS, 22(3), 71-82. https://doi.org/10.2307/467655

Putnam, A. (2011). Mothering Violence: Ferocious Female Resistance in Toni Morrison's The Bluest Eye, Sula, Beloved, and A Mercy. Black Women, Gender and Families, 5(2), 25-43. https://doi.org/10.5406/blacwomegendfami.5.2.0025

Rice, A. (1999). Erupting Funk: The Political Style of Toni Morrison's Tar Baby and The Bluest Eye. In D. L. Madsen, (ed.), Post-Colonial Literatures: Expanding the Canon (133-147). London, Pluto Press.

Rigney, B. H. (1991). The Voices of Toni Morrison. Columbus: Ohio State University Press.

Rokotnitz, N. (2007). Constructing Cognitive Scaffolding Through Embodied Receptiveness: Toni Morrison's The Bluest Eye. Style, 41(4), 385-408.

Roynon, T. (2013). The Cambridge Introduction to Toni Morrison. Cambridge: Cambridge University Press.

Salvatore, A. T. (2002). Toni Morrison's New Bildungsromane: Paired Characters and Antithetical Form in The Bluest Eye, Sula, and Beloved. Journal of Narrative Theory, 32(2), 154-178. https://doi.org/10.1353/jnt.2011.0040

Showalter, E. (1977). A Literature of Their Own: British Women Novelists from Brontë to Lessing. Princeton, New Jersey: Princeton University Press.

Small-McCarthy, R. (1995). From 'The Bluest Eye' to 'Jazz': A Retrospective of Toni Morrison's Literary Sounds. Discourse: Studies in the Cultural Politics of Education, 16(3), 377-389. https://doi.org/10.1080/0159630950160307

Softing, I., (1995). Carnival and Black American Music as Counterculture in Toni Morrison's The Bluest Eye and Jazz. American Studies in Scandinavia, 27(2), 81-102.

Walther, M. L. (1990). Out of Sight: Toni Morrison's Revision of Beauty. Black American Literature Forum, 24(4), 775-89. https://doi.org/10.2307/3041802

Werrlein, D. T. (2005). Not So Fast, Dick and Jane: Reimagining Childhood and Nation in The Bluest Eye. MELUS, 30(4), 53-72. https://doi.org/10.1093/melus/30.4.53

Willis, S. (1993). Eruptions of Funk: Historicizing Toni Morrison. In Gates and Appia, (eds), 308-329.

Wilson, A. (1988, October 20). August Wilson on Blackness. Interview by B. Moyers. [Online video and transcript]. Retrieved from https://billmoyers.com/content/august-wilson/

Wong, S. (1990). Transgression as Poesis in The Bluest Eye. Callaloo, 13(3), 471-81. http://www.jstor.org/stable/2931331.

\section{Copyrights}

Copyright for this article is retained by the author(s), with first publication rights granted to the journal.

This is an open-access article distributed under the terms and conditions of the Creative Commons Attribution license (http://creativecommons.org/licenses/by/4.0/). 